\title{
Physical, chemical, sensory and mineral characterization of salty muffins enriched with Tetragonia tetragonoides
}

\section{Caracterização física, química, sensorial e mineral de muffins salgados enriquecidos com Tetragonia tetragonoides}

\author{
Thales Henrique Barreto Ferreira ${ }^{1 *}$ (1), Angélica Pimenta de Lima dos Reis ${ }^{2}$, \\ Leticia da Silva Souza², Hygor de Oliveira Rodrigues², Rita de Cássia Avellaneda Guimarães ${ }^{3}$, \\ Cláudia Leite Munhoz ${ }^{2}$
}

${ }^{1}$ Universidade Federal da Grande Dourados (UFGD), Faculdade de Engenharia (FAEN), Dourados/MS - Brasil

${ }^{2}$ Instituto Federal do Mato Grosso do Sul (IFMS), campus Coxim, Coxim/MS - Brasil

${ }^{3}$ Universidade Federal do Mato Grosso do Sul (UFMS), Faculdade de Ciências farmacêuticas, Alimentos e Nutrição

(FACFAN), Campo Grande/MS - Brasil

${ }^{*}$ Corresponding Author: Thales Henrique Barreto Ferreira, Federal University of Grande Dourados (UFGD),

Faculty of Engineering (FAEN), Highway 7 Dourados - Itahum, km 12, CP: 533, CEP: 79804-970, Dourados/MS -

Brazil, e-mail: thales_barreto25@hotmail.com

Cite as: Ferreira, T. H. B., Reis, A. P. L., Souza, L. S., Rodrigues, H. O., Guimarães, R. C. A., \& Munhoz, C. L.

(2021). Physical, chemical, sensory and mineral characterization of salty muffins enriched with Tetragonia

tetragonoides. Brazilian Journal of Food Technology, 24, e2020189. https://doi.org/10.1590/1981-6723.18920

\begin{abstract}
The preparation of bakery products is expanding, mainly due to the possibility of adding other ingredients, in order to enrich them nutritionally. Spinach (Tetragonia tetragonoides) is a vegetable widely used, although its stem that has great potential for use, is still considered a waste and discarded. Based on the aforementioned information, this work aims to elaborate and characterize physical, chemical, sensory and minerals of salty muffins enriched with T. tetragonoides. Four formulations of salty muffins were prepared as following: Standard Formulation (F1); Formulation with addition of spinach leaves (F2); Formulation with addition of spinach stems (F3); Formulation with addition of spinach leaves and stems (F4). The physical and chemical characterization of the leaves and stems of T. tetragonoides was done by quantifying the moisture, residue mineral fixed, proteins, color and minerals. Muffins were characterized by analyzing moisture, fixed mineral residue, protein, total reducing sugars and instrumental analysis of color and texture; sensory and minerals. The muffins showed a predominant green color, due to the addition of spinach. However, stems, leaves and muffins have a high content of minerals, especially calcium and iron. The incorporation of vegetables in the formulations provided an increase in protein content, in addition to expressive sensory acceptance. Feasibility is observed in the production of savory muffins with the addition of leaves and stems, thus using the entire vegetable and avoiding food waste.
\end{abstract}

Keywords: Spinach; leaves; stems; use of waste; sensory acceptability; adding value.

\section{Resumo}

A elaboração de produtos de panificação está se expandindo, principalmente devido à possibilidade de adição de outros ingredientes, a fim de enriquecê-los nutricionalmente. O espinafre (Tetragonia tetragonoides) é um vegetal 
amplamente utilizado, embora seu caule, que tem grande potencial de uso, ainda seja considerado um resíduo, sendo, por isso, descartado. Com base no exposto, este trabalho tem como objetivos elaborar e caracterizar aspectos físicos, químicos, sensoriais e minerais de muffins salgados enriquecidos com Tetragonia tetragonoides. Quatro formulações de muffins salgados foram elaboradas: Formulação Padrão (F1), Formulação com adição de folhas de espinafre (F2), Formulação com adição de caules de espinafre (F3) e Formulação com adição de folhas e caules de espinafre (F4). As caracterizações física e química das folhas e caules de Tetragonia tetragonoides foram feitas por meio da quantificação da umidade, do resíduo mineral fixado, das proteínas, da cor e dos minerais. Os muffins foram caracterizados pela análise de umidade, resíduo mineral fixo, proteína, açúcares redutores totais e cor e textura instrumental, além da análise sensorial e dos minerais. Os muffins apresentaram cor predominantemente verde, devido à adição de espinafre. Caules, folhas e muffins possuem alto teor de minerais, principalmente cálcio e ferro. A incorporação de vegetais nas formulações proporcionou aumento no teor de proteína e umidade, além de expressiva aceitação sensorial. Há viabilidade de produção de muffins saborosos com adição de folhas e caules, aproveitando assim o vegetal integralmente e evitando a geração de resíduos.

Palavras-chave: Espinafre; folhas; caules; aproveitamento de resíduos; aceitabilidade sensorial.

\section{Introduction}

The development of food products with the use of alternative raw materials has been intensified in recent years, in order to increase and improve nutritional quality, without compromising the sensory characteristics of the final product. Among these, it has been highlighted the bakery products, especially, salty muffins. Such highlighted issues related to it are mainly associated with the possibility of adding new ingredients in the muffin formulations, even parts of vegetables that are considered waste, such as spinach stems (T. tetragonoides) (Barros et al., 2019; Ferreira et al., 2019; Augusto et al., 2017, Ferreira \& Freitas, 2019).

Spinach can be used in product enrichment or as an ingredient in bakery products, since its constitution of polysaccharides, lignin, resistant oligosaccharides and Resistant Starch (RS), among others, can replace fat or act as a stabilizing, thickening, emulsifying agent (Mauro et al., 2010). In addition, the integral incorporation of this vegetable into a new product, such as muffins, can contribute to the increase in the content of vitamins, proteins and minerals, especially calcium and iron, in addition to being rich in bioactive compounds, making changes to the final product to provide higher quality and amount of compounds beneficial to the human organism (Galla et al., 2017; Azevedo, 2012).

Based on the aforementioned information, this work aimed at the elaboration as well as the physical, chemical, sensory and mineral characterization of salty muffins enriched with leaves and stems of T. tetragonoides.

\section{Material and methods}

Spinach leaves and stems (T. tetragonoides) were collected in the municipality of Coxim, in the state of

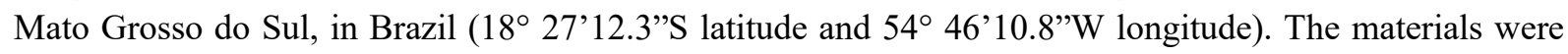
stored in thermal boxes, transported to the Fruit and Vegetable Laboratory of the Federal Institute of Mato Grosso do Sul, and they were selected according to their physical integrity, were sanitized by immersion in Dihydrated Sodium Dichloroisocyanurate (Sumaveg, by Diversey Lever) at $200 \mathrm{ppm}$ of active chlorine for $20 \mathrm{~min}$, packed in polyethylene packaging and stored at $16^{\circ} \mathrm{C}$, until use. The other ingredients used in the formulations were purchased from a local store.

\subsection{Salty muffin formulations}

Four formulations of salty muffins were prepared as following: Standard Formulation (F1); Formulation with addition of spinach leaves (F2); Formulation with addition of spinach stems (F3); and Formulation with 
addition of spinach leaves and stems (F4); in addition to following the same proportion for the other ingredients (Table 1).

Table 1. Formulation of salty muffins enriched with spinach (Tetragonia tetragonoides).

\begin{tabular}{ccccc}
\hline Ingredients & F1 & F2 & F3 & F4 \\
\hline Wheat flour $(\mathrm{g})$ & 145 & 145 & 145 & 145 \\
\hline Spinach leaves $(\mathrm{g})$ & $*$ & $*$ & 30 & 15 \\
\hline Spinach stems $(\mathrm{g})$ & $*$ & 30 & $*$ & 15 \\
\hline Egg $(\mathrm{g})$ & 100 & 100 & 85 & 100 \\
\hline Oil $(\mathrm{mL})$ & 85 & 12 & 12 & 12 \\
\hline Chemical yeast $(\mathrm{g})$ & 12 & 240 & 240 & 240 \\
\hline Milk $(\mathrm{mL})$ & 240 & 100 & 100 & 100 \\
\hline Mozzarella cheese $(\mathrm{g})$ & 100 & & & 12 \\
\hline
\end{tabular}

*Does not have.

The standard muffin formulation was prepared according to Ferreira et al. (2019) with some modifications. In a blend (Britânia) homogeneity consisting of the oil $(85 \mathrm{~mL})$, eggs $(100 \mathrm{~g})$, mozzarella $(100 \mathrm{~g})$ and milk $(240 \mathrm{~mL})$, spinach leaves and stems (according to the formulations) were added. Then, they were mixed with dry ingredients (wheat flour and chemical yeast). The dough was shaped with the aid of a circular shape and the muffins were baked at $180{ }^{\circ} \mathrm{C}$ for 20 minutes. These muffins were cooled to room temperature and packed in polyethylene bags for later physical, chemical and sensory analysis.

\subsection{Physical and chemical characterization}

The diameter and thickness ( $\mathrm{mm}$ ) of the muffins were determined with the aid of a digital caliper (Digimess), according to the procedures described in the 10-50D method of AACC (1995).

Muffins, leaves and stems spinach were characterized when the moisture content was determined by the gravimetric method under study at $70{ }^{\circ} \mathrm{C}$ until constant weight was obtained (Association of Oficial Analytical Chemistral, 1995). The fixed mineral residue content was calculated by burning excess sugar with a hot plate, followed by the muffle incineration (CE-800/S4 - CIENLAB) at $550{ }^{\circ} \mathrm{C}$, until light fixed mineral residue and constant weight were obtained (Association of Oficial Analytical Chemistral, 1992). Protein quantification was performed using the micro-Kjedahl method, which quantifies the total nitrogen content, converting nitrogen into protein by multiplying the factor 6.25 (Association of Oficial Analytical Chemistral, 1995), in addition, the content of reducing sugars in muffins totals determined by the Eynon-Lane method (Association of Oficial Analytical Chemistral, 1992), the results being expressed on a wet basis.

The color parameters were evaluated by the instrumental method at five points of each sample, using the digital colorimeter CR 400/410 (Konica Minolta), with determination of the parameters $L^{*}$ (luminosity), $a^{*}$ (color variation from green to red), $b^{*}$ (color variation from blue to yellow), the ${ }^{\circ} \mathrm{h}$ parameter that defines the color tone and the $\mathrm{C}$ parameter that defines the color saturation or chromaticity.

The texture profile of the muffins was performed on a Stable Micro Systems texturometer Model TAXT2i (Goldaming, England) with a flat-bottomed stainless steel cylindrical probe (36 mm in diameter), $10 \mathrm{~cm}$ distance and speed pre-test, test and post-tests of 5, 2 and $2 \mathrm{~mm} . \mathrm{s}^{-1}$, respectively, comprising the time of $5 \mathrm{~s}$ between the two compressions. The parameters analyzed were: Hardness; elasticity; cohesiveness; chewability; and resistance.

\subsection{Mineral characterization}

The mineral content was determined from the mineral residue fixed in a dry sample by acid digestion in concentrated nitric acid, according to Salinas and Garcia modified (1985). The levels of calcium, iron, magnesium, manganese, potassium and sodium were determined in an atomic absorption spectrophotometer (Shimadzu, model AA-7000 Series). 


\subsection{Sensory analysis}

Sensory analysis was performed at the Sensory Analysis Laboratory of the Federal Institute of Mato Grosso do Sul, Coxim campus. Acceptance tests were performed with 60 untrained judges, who received four samples coded with three digits.

Together, they received an evaluation form, with a test of acceptability of the samples by means of a hedonic scale of nine (9) points, ranging from 1 (dislike very much) and 9 (like very much). The attributes evaluated on the sheet were appearance, color, aroma, texture, flavor, spinach flavor, sweetness and overall quality. Each judge also indicated the purchase intention for the evaluated samples (Dutcosky, 2013).

Samples with a score greater than or equal to six (6) (somewhat like) were considered accepted. In addition, the Acceptance Index (AI) of the sensory attributes (Equation 1) was calculated.

$$
I A(\%)=A \times \frac{100}{B}
$$

Where $A$ is the average score obtained for the attribute and $B$ is the maximum score given to the attribute.

Each panelist should also indicate their favorite sample and purchase intention using the structured five (5) point scale, varying between "would certainly buy it" and "certainly would not buy it" (Dutcosky, 2013).

\subsection{Statistical analysis}

All analyzes were performed in triplicate and the results were presented by the mean $(n=3)$ and Standard Deviation (SD). The comparisons between the groups were submitted to Analysis of Variance (ANOVA) and when significant, they were compared using the Tukey's test at 5\% probability of error.

\section{Results and discussion}

Table 2 presents the physical and chemical characterization of spinach leaves and stems (T. tetragonoides). The moisture content of the leaves and spinach stems did not differ significantly $(p>0.05)$ from each other; however the fixed mineral residue and protein content showed a statistical difference. The values for the

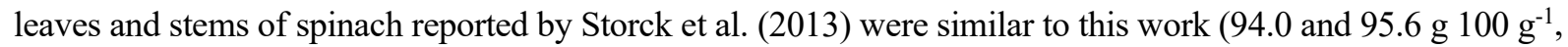
respectively). The fixed mineral residue content was $58 \%$ higher in the stems when compared to the spinach

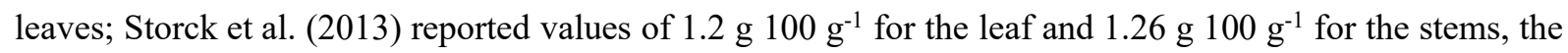
differences with the work data may be related to climatic differences and time of planting. Larger amounts

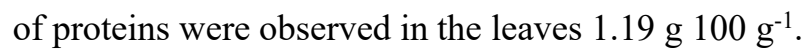

Table 2. Physical and chemical characterization of leaves and stems of spinach (Tetragonia tetragonoides).

\begin{tabular}{ccc}
\hline Characteristic & Leaves & Stems \\
\hline Moisture $\left(\mathrm{g} 100 \mathrm{~g}^{-1}\right)$ & $93.31 \pm 0.20 \mathrm{a}$ & $93.28 \pm 0.21 \mathrm{a}$ \\
\hline Fixed mineral residue $\left(\mathrm{g} 100 \mathrm{~g}^{-1}\right)$ & $1.90 \pm 0.20 \mathrm{a}$ & $1.20 \pm 0.13 \mathrm{~b}$ \\
\hline Proteins $\left(\mathrm{g} 100 \mathrm{~g}^{-1}\right)$ & $1.19 \pm 0.09 \mathrm{a}$ & $0.87 \pm 0.10 \mathrm{~b}$ \\
\hline Color parameters & \\
\hline$L^{*}$ & $37.49 \pm 1.69 \mathrm{a}$ & $36.65 \pm 1.69 \mathrm{a}$ \\
\hline$a^{*}$ & $-14.42 \pm 0.16 \mathrm{a}$ & $-12.38 \pm 0.16 \mathrm{~b}$ \\
\hline$b^{*}$ & $19.37 \pm 0.33 \mathrm{a}$ & $20.61 \pm 0.33 \mathrm{a}$ \\
\hline$C$ & $24.15 \pm 0.19 \mathrm{a}$ & $25.78 \pm 0.19 \mathrm{a}$ \\
\hline${ }^{\circ} \mathrm{h}$ & $126.66 \pm 0.76 \mathrm{a}$ & $118.67 \pm 0.76 \mathrm{~b}$
\end{tabular}

*Same letters on the same line do not differ from each other $(p>0.05)$ by the Tukey's test. 
Regarding the instrumental color parameters, it could be observed that both the leaves and the stems had a predominantly green color, especially the leaves, by the coordinate $a^{*}$ and its negative values $\left(-a^{*}=\right.$ green and $+a^{*}$ red $)$. The predominant presence of dark green is associated with chlorophyll, a bioactive compound with anti-cancer properties, in addition to inhibiting free radicals (Rocha \& Reed, 2014). The other coordinates did not show significant differences ( $p>0.05)$, although Rezende (2013) reported brightness values similar to that of this work for spinach leaves $\left(L^{*}=35.10\right)$ and the $b^{*}$ coordinate (18.10).

The similarity of the results obtained between the leaves and stems expands the possibility of using both parts in food processing and production, thus, the parts of the vegetable that are considered a waste may gain technological advantage.

The physical and chemical characterization of salty muffins enriched with spinach ( $T$. tetragonoides) is shown in Table 3. The addition of spinach leaves in formulations F3 and F4 influenced the diameter of the muffins, unlike the thickness, where no significant difference was observed between the samples.

Table 3. Physical and chemical characterization of salty muffins enriched with spinach (Tetragonia tetragonoides).

\begin{tabular}{|c|c|c|c|c|}
\hline \multirow{2}{*}{ Characteristics } & \multicolumn{4}{|c|}{ Formulations } \\
\hline & F1 & F2 & F3 & F4 \\
\hline Diameter $(\mathrm{cm})$ & $6.18 \pm 0.05 \mathrm{a}$ & $6.25 \pm 0.06 \mathrm{a}$ & $6.02 \pm 0.02 b$ & $5.95 \pm 0.04 \mathrm{~b}$ \\
\hline Thickness (cm) & $3.46 \pm 0.22 \mathrm{a}$ & $3.56 \pm 0.22 \mathrm{a}$ & $3.28 \pm 0.03 \mathrm{a}$ & $3.57 \pm 0.03 \mathrm{a}$ \\
\hline Moisture (g $\left.100 \mathrm{~g}^{-1}\right)$ & $38.56 \pm 4.96 \mathrm{a}$ & $39.35 \pm 0.95 a$ & $40.25 \pm 1.30 \mathrm{a}$ & $40.99 \pm 0.32 a$ \\
\hline Fixed Mineral residue $\left(\mathrm{g} 100 \mathrm{~g}^{-1}\right)$ & $2.28 \pm 0.56 \mathrm{a}$ & $2.36 \pm 0.14 \mathrm{a}$ & $2.39 \pm 0.03 a$ & $2.37 \pm 0.08 \mathrm{a}$ \\
\hline 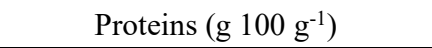 & $3.86 \pm 0.26 b$ & $5.04 \pm 0.02 \mathrm{a}$ & $5.00 \pm 0.01 \mathrm{a}$ & $5.15 \pm 0.24 \mathrm{a}$ \\
\hline Reducing sugars (g $100 \mathrm{~g}^{-1}$ ) & $64.11 \pm 1.74 a$ & $55.59 \pm 1.10 \mathrm{~b}$ & $53.76 \pm 0.82 b$ & $43.48 \pm 1.34 c$ \\
\hline \multicolumn{5}{|l|}{ Color parameters } \\
\hline$L^{*}$ & $44.99 \pm 5.27 \mathrm{~b}$ & $48.19 \pm 4.65 \mathrm{a}$ & $47.05 \pm 3.07 \mathrm{a}$ & $48.45 \pm 2.08 \mathrm{a}$ \\
\hline$a^{*}$ & $6.21 \pm 5.82 \mathrm{a}$ & $-1.76 \pm 4.33 a$ & $5.96 \pm 4.23 \mathrm{a}$ & $0.68 \pm 3.01 \mathrm{a}$ \\
\hline$b^{*}$ & $31.45 \pm 3.49 \mathrm{a}$ & $33.77 \pm 1.21 \mathrm{a}$ & $33.17 \pm 1.63 \mathrm{a}$ & $23.56 \pm 2.41 \mathrm{~b}$ \\
\hline $\mathrm{C}^{*}$ & $32.34 \pm 4.42 \mathrm{a}$ & $34.00 \pm 1.37 \mathrm{a}$ & $33.95 \pm 2.27 \mathrm{a}$ & $33.69 \pm 2.58 \mathrm{a}$ \\
\hline${ }^{\circ} \mathrm{h}$ & $79.65 \pm 9.27 \mathrm{a}$ & $92.96 \pm 7.15 b$ & $79.60 \pm 7.43 a$ & $88.55 \pm 6.56 \mathrm{~b}$ \\
\hline
\end{tabular}

Standard muffin formulation (F1), Muffin formulation with addition of spinach leaves (F2), Muffin formulation with addition of spinach stems (F3) Muffin formulation with addition of spinach leaves and stems (F4). * Same letters on the same line do not differ from each other $(p>0.05)$ by the Tukey's test.

The fixed mineral residue content did not show significant differences $(p>0.05)$ between the formulations, values were observed for the formulations with the addition of spinach F2, F3 and F4 $(2.36 ; 2.39$ and $2.37 \mathrm{~g}$ $100 \mathrm{~g}^{-1}$, respectively). Values were similar to those reported by Santos \& Boêno (2016) for muffins with

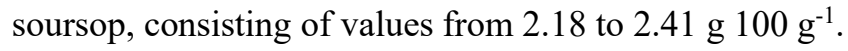

The amount of proteins was directly influenced by the addition of leaves and stems of $T$. tetragonoides, observing statistical difference between the formulations with and without the addition of vegetables, with the addition of spinach, then, it should be noted an increase in the amount of protein content in muffins. Silva

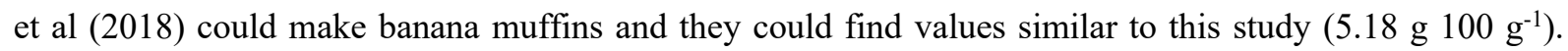
Chavez et al. (2016) showed that enriching foods raises the amount of protein in the product by 30 to $40 \%$. According to Silva et al (2018) with increased protein, there may be an increase in essential amino acids such as lysine and tryptophan.

Regarding reducing sugars, the highest value was observed in the standard formulation F1 (64.11 g $\left.100 \mathrm{~g}^{-1}\right)$

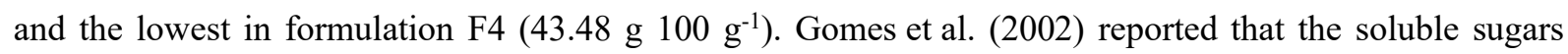


present in foods in combined form are responsible for sweetness, flavor and texture, when properly combined with structural polysaccharides.

For the luminosity $\left(L^{*}\right)$ the values ranged from 44.99 to 48.45 , with the most desirable by most consumers of bread products being lighter products, in this way, correlating that muffins with the addition of spinach are better accepted visually (Guimarães et al., 2014). As observed in the leaves, the muffins of formulations $\mathrm{F} 2$ and $\mathrm{F} 4$ obtained a predominantly green color, observed through the coordinate $a^{*}\left(-a^{*}=\right.$ green and $+a^{*}$ red), precisely influenced by the color of the leaves in natura.

The chromaticity value $\left(C^{*}\right)$ describes the color saturation or intensity; in this sense, correlate that higher $C^{*}$ values have more intense color characteristics; thus, they are better accepted (Kirca et al., 2007).

As no significant difference was observed between the samples $(p>0.05)$, it could be concluded that all samples are equivalent in terms of their acceptance, according to the color coordinate.

The instrumental Texture Profile Analysis (TPA) of salty muffins enriched with spinach (T. tetragonoides) is shown in Table 4. The incorporation of spinach, especially in the F2 and F4 formulations that used the leaves, there was an increase in the hardness of these samples when compared to the standard (F1); this is partly due to the high hygroscopicity of the spinach leaves allowing the formation of a more cohesive and stable network structure. In other studies on the formulation of muffins with different types of resistant starches, this texture characteristic was also greater as new ingredients were incorporated into the formulations (Sowmya et al., 2009; Sanz et al., 2009).

Table 4. Instrumental Texture Profile Analysis (TPA) of salty muffins enriched with spinach (Tetragonia tetragonoides).

\begin{tabular}{ccccc}
\hline Texture profile $(\boldsymbol{T P A})$ & F1 & F2 & F3 & F4 \\
\hline Hardness $(\mathrm{g})$ & $1053.46 \pm 47.42^{\mathrm{c}}$ & $1126.34 \pm 31.94^{\mathrm{b}}$ & $1078.85 \pm 42.31^{\mathrm{a}}$ & $1097.86 \pm 46.57^{\mathrm{a}}$ \\
\hline Elasticity $(\mathrm{adm})$ & $0.90 \pm 0.05^{\mathrm{a}}$ & $0.95 \pm 0.01^{\mathrm{a}}$ & $0.96 \pm 0.01^{\mathrm{a}}$ & $0.92 \pm 0.02^{\mathrm{a}}$ \\
\hline Cohesiveness $(\mathrm{adm})$ & $0.62 \pm 0.073^{\mathrm{a}}$ & $0.70 \pm 0.09^{\mathrm{a}}$ & $0.68 \pm 0.03^{\mathrm{a}}$ & $0.65 \pm 0.02^{\mathrm{a}}$ \\
\hline Chewbility $(\mathrm{g})$ & $235.12 \pm 31.02^{\mathrm{c}}$ & $281.30 \pm 81.21^{\mathrm{b}}$ & $306.46 \pm 23.49^{\mathrm{a}}$ & $296.46 \pm 2349^{\mathrm{a}}$ \\
\hline Resistance & $0.27 \pm 0.02^{\mathrm{b}}$ & $0.26 \pm 0.05^{\mathrm{a}}$ & $0.31 \pm 0.02^{\mathrm{a}}$ & $0.30 \pm 0.01^{\mathrm{a}}$ \\
\hline
\end{tabular}

Standard muffin formulation (F1), Muffin formulation with addition ofspinach leaves (F2), Muffin formulation with addition of spinach stems (F3) Muffin formulation with addition of spinach leaves and stems (F4). * Same letters on the same line do not differ from each other $(p>0.05)$ by the Tukey's test.

There were no significant differences $(p>0.05$ ) for elasticity, cohesiveness and resistance. The chewiness that represents the energy required for grinding a solid food, in which it is ready to be swallowed, was greater in formulation F3 and F4, and this can be associated with the fact that the stems are more resistant and rigid when compared to the leaves.

Table 5 shows the mineral content of salty muffins enriched with spinach (T. tetragonoides).

A food is considered to have a high mineral content when it contains at least $30 \%$ of the Recommended Daily Intake (RDI) of reference, in $100 \mathrm{~g}$ of solid food and, as a source, when its content is at least $15 \%$

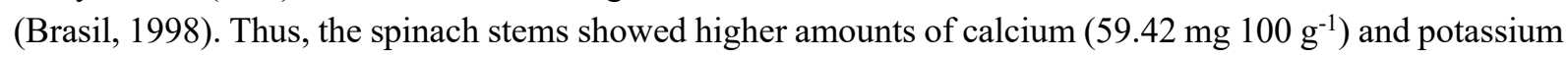
(223.27 mg $100 \mathrm{~g}^{-1}$ ), thus, the formulations regarding F2 and F4 muffins with spinach stems also presented

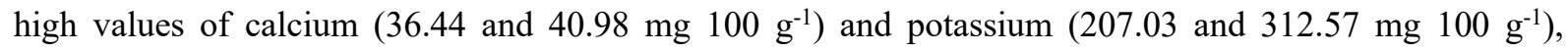
respectively. Spinach muffins can contribute in considerable proportions to the recommended dietary intake, being alternative sources of nutrients. 
Table 5. Mineral content of salty muffins enriched with spinach (Tetragonia tetragonoides).

\begin{tabular}{|c|c|c|c|c|c|c|}
\hline \multirow{2}{*}{$\begin{array}{c}\text { Mineral } \\
\left({\left.\mathrm{mg} 100 \mathrm{~g}^{-1}\right)}^{-1}\right)\end{array}$} & \multirow{2}{*}{ Leaves } & \multirow{2}{*}{ Steams } & \multicolumn{4}{|c|}{ Formulations } \\
\hline & & & F1 & F2 & F3 & F4 \\
\hline Calcium & $39.69 \pm 0.19 \mathrm{a}$ & $59.42 \pm 0.67 \mathrm{a}$ & $30.33 \pm 2.57 \mathrm{a}$ & $36.44 \pm 3.46 b$ & $47.73 \pm 2.38 b$ & $40.98 \pm 2.12 b$ \\
\hline Iron & $6.95 \pm 0.68 \mathrm{a}$ & $3.90 \pm 0.42 \mathrm{a}$ & $3.44 \pm 0.21 \mathrm{a}$ & $4.20 \pm 1.38 b$ & $3.93 \pm 0.27 b$ & $4.60 \pm 0.90 b$ \\
\hline Magnesium & $140.24 \pm 7.45 \mathrm{a}$ & $48.76 \pm 4.55 \mathrm{a}$ & $75.21 \pm 5.65 a$ & $81.23 \pm 2.22 \mathrm{a}$ & $76.15 \pm 3.05 b$ & $80.95 \pm 4.84 b$ \\
\hline Manganese & $2.25 \pm 0.31 \mathrm{a}$ & $1.17 \pm 0.11 \mathrm{a}$ & $1.14 \pm 0.21 \mathrm{a}$ & $1.23 \pm 0.04 \mathrm{a}$ & $1.14 \pm 0.04 \mathrm{a}$ & $1.17 \pm 0.12 \mathrm{a}$ \\
\hline Potassium & $221.89 \pm 6.24 b$ & $223.27 \pm 4.97 b$ & $170.14 \pm 7.35 \mathrm{c}$ & $207.03 \pm 3.43 b$ & $202.31 \pm 4.73 b$ & $312.57 \pm 5.72 \mathrm{a}$ \\
\hline Sodium & $34.13 \pm 2.89 a$ & $27.04 \pm 2.45 \mathrm{a}$ & $51.08 \pm 1.64 \mathrm{a}$ & $51.09 \pm 3.75 \mathrm{a}$ & $50.86 \pm 7.00 \mathrm{a}$ & $51.67 \pm 2.90 \mathrm{a}$ \\
\hline
\end{tabular}

The averages obtained for the sensory acceptance and acceptability index of salty muffins enriched with spinach are shown in Table 6 . The samples did not differ statistically from each other in any attribute $(p>0.05)$, obtaining scores higher than 6.0 (slightly liked) in all of them, causing the samples to be considered as accepted by the judges (Dutcosky, 2013). The acceptance rate of the samples was greater than $75 \%$, Dutcosky (2013) showed that for a sample to be considered as accepted, it must have an acceptance rate greater than $70 \%$, thus, the four formulations are considered as accepted for consumption by the judges.

Table 6. Sensory acceptability of salty muffins enriched with spinach (Tetragonia tetragonoides).

\begin{tabular}{|c|c|c|c|c|}
\hline Attributes * & F1 & F2 & F3 & F4 \\
\hline Appearance & $7.8 \mathrm{a}$ & $7.5 \mathrm{a}$ & $7.6 \mathrm{a}$ & $7.3 \mathrm{a}$ \\
\hline $\mathrm{AI}(\%)$ & $86.67 \mathrm{a}$ & $83.34 \mathrm{~b}$ & $84.45 b$ & $81.12 \mathrm{c}$ \\
\hline Color & $7.7 \mathrm{a}$ & $7.9 \mathrm{a}$ & $7.7 \mathrm{a}$ & $7.6 \mathrm{a}$ \\
\hline $\mathrm{AI}(\%)$ & $85.56 \mathrm{~b}$ & $87.78 \mathrm{a}$ & $85.56 \mathrm{~b}$ & $84.45 \mathrm{~b}$ \\
\hline Aroma & $7.7 \mathrm{a}$ & $7.5 \mathrm{a}$ & $7.8 \mathrm{a}$ & $7.6 \mathrm{a}$ \\
\hline $\mathrm{AI}(\%)$ & $85.56 \mathrm{ac}$ & $83.34 \mathrm{~b}$ & $86.67 \mathrm{a}$ & $84.45 \mathrm{bc}$ \\
\hline Texture & $7.9 \mathrm{a}$ & $8.1 \mathrm{a}$ & $8.0 \mathrm{a}$ & $7.9 \mathrm{a}$ \\
\hline $\mathrm{AI}(\%)$ & $87.78 \mathrm{~b}$ & $90 \mathrm{a}$ & $88.89 \mathrm{ab}$ & $87.78 \mathrm{~b}$ \\
\hline Flavor & $7.7 \mathrm{a}$ & $7.6 \mathrm{a}$ & $7.9 \mathrm{a}$ & $7.8 \mathrm{a}$ \\
\hline $\mathrm{AI}(\%)$ & $85.56 \mathrm{bc}$ & $84.45 \mathrm{c}$ & $87.78 \mathrm{a}$ & $86.67 \mathrm{ab}$ \\
\hline Flavor of spinach & $6.7 \mathrm{a}$ & $6.8 \mathrm{a}$ & $6.6 \mathrm{a}$ & $7.1 \mathrm{a}$ \\
\hline $\mathrm{AI}(\%)$ & $74.45 \mathrm{~b}$ & $75.56 \mathrm{~b}$ & $73.33 \mathrm{~b}$ & $78.89 \mathrm{a}$ \\
\hline Salt & $7.2 \mathrm{a}$ & $7.1 \mathrm{a}$ & $7.4 \mathrm{a}$ & $7.4 \mathrm{a}$ \\
\hline $\mathrm{AI}(\%)$ & $80 \mathrm{ab}$ & $78.89 \mathrm{~b}$ & $82.22 \mathrm{a}$ & $82.22 \mathrm{a}$ \\
\hline Global quality & $7.6 \mathrm{a}$ & $7.6 \mathrm{a}$ & $7.5 \mathrm{a}$ & $7.5 \mathrm{a}$ \\
\hline $\mathrm{AI}(\%)$ & $84.45 \mathrm{a}$ & $84.45 \mathrm{a}$ & $83.34 \mathrm{a}$ & $83.34 \mathrm{a}$ \\
\hline
\end{tabular}

Standard muffin formulation (F1), Muffin formulation with addtion of spinach leaves (F2), Muffin formulation with addition of spinach stems (F3) Muffin formulation with addition of spinach leaves and stems (F4). * Same letters on the same line do not differ from each other $(p>0.05)$ by the Tukey's test.

Augusto et al. (2017) had an AI of $82.4 \%$ for cupcakes made with flours of spinach and cabbage stalks, which shows the good acceptability of products enriched with vegetables, which can be an alternative product to be offered.

Figure 1 shows the intention to purchase muffins with the addition of spinach. It is possible to observe that the data obtained showed that the product had a high percentage of purchase intention (in the market), with $32 \%$ of people "certainly would buy it" and $44 \%$ "probably would buy it". 


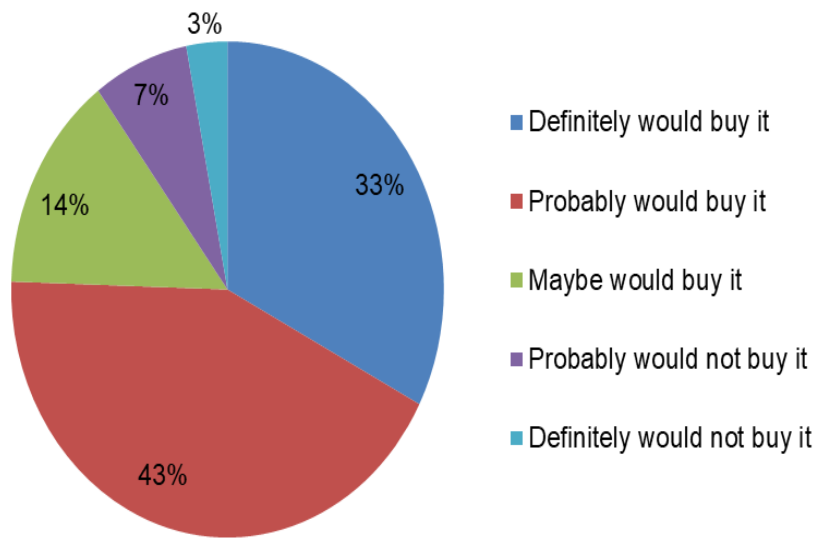

Figure 1. Intention to purchase salty muffins enriched with spinach (Tetragonia tetragonoides).

\section{Conclusion}

Both leaves and stems have enormous potential for use, due to their nutritional composition and high mineral content. Feasibility is observed in the production of salty muffins with the addition of spinach leaves and stalks, thus using the entire vegetable and avoiding food waste.

The production of muffins, with parts of vegetables, provided a high content of iron and calcium, in addition to the expressive increase in the amount of proteins, mainly for formulation F4, with the addition of both parts. The high scores of sensory acceptability, especially for the overall quality and flavor, showed the potential for the production of tasty muffins enriched with $T$. tetragonoides.

\section{References}

American Association of Cereal Chemists - AACC. (1995). Approved methods of the AACC (9. ed.). St. Paul: AACC, 1200p.

Association of Oficial Analytical Chemistral - AOAC. (1992). Official methods of Analysis of the Association of Official Analytical Chemistry (11th ed.). Arlington: AOAC.

Association of Oficial Analytical Chemistral - AOAC. (1995). Official methods of Analysis of the Association of Official Analytical Chemistry (16th ed.). Arlington: AOAC.

Augusto, G., Zanlourensi, C. B., Chiconatto, P., \& Schmitt, P. (2017). Aceitação de cupcakes com farinha de talos de couve manteiga e farinha de talos de espinafre por escolares do município de Prudentópolis-PR. Revista Brasileira de Obesidade, Nutrição e Emagrecimento, 68, 731-737.

Azevedo, F. L. A. A. (2012). Valor nutricional, capacidade antioxidante e utilização de folhas de espinafre (Tetragonia tetragonoides) em pó como ingrediente de pão de forma (Tese de doutorado). Universidade Federal da Paraíba, João Pessoa. $130 \mathrm{p}$.

Barros, L. S., Ribeiro, N. L. A., Ferreira, W. C. O., Nobre, M. L. M., Alves, T. L., Lima, A. C. S., Figueiredo, R. W., \& Pinho, L. X. (2019). Use of flavored pineapple waste flour in cookies production. Brazilian Journal of Development, 5, 113-120.

Brasil. Ministério da Saúde. Agência Nacional de Vigilância Sanitária. (1998, janeiro 13). Portaria $n^{\circ} 27$ de 13 de janeiro de 1998: Regulamento Técnico sobre a Informação Nutricional. Diário Oficial [da] República Federativa do Brasil, Brasília.

Chavez, F., Barca, A. M. C., Ilhas-Rubio, A. R., Marti, A., Marengo, M., Pagani, M. A., Bonomi, F., \& lametti, S. (2016). Molecular rearrangements in extrusion processes for the production of amaranth-enriched, gluten-free rice pasta. LebensmittelWissenschaft + Technologie, 47, 233-240. http://dx.doi.org/10.1016/j.Iwt.2012.01.040

Dutcosky, S. D. (2013). Análise sensorial de alimentos. Curitiba: Champagnat

Ferreira, T. H. B., Basaglia, R. R., Cunha, T. M. P., \& Argandona, E. J. S. (2019). Muffins de beterraba adicionados de ora-pronobis: caracterização física. Anais do III Sinatex, 3, 179-184.

Ferreira, T. H. B., \& Freitas, M. L. F. (2019). Production, physical, chemical and sensory evaluation of dried banana (Musa Cavendish). Emirates Journal of Food and Agriculture, 31, 102-108. http://dx.doi.org/10.9755/ejfa.2019.v31.i2.1912

Galla, N. R., Pamidighantam, P. R., Karakala, B., Gurusiddaiah, M. R., \& Akula, S. (2017). Nutritional, textural and sensory quality of biscuits supplemented with spinach (Spinacia oleracea L.). International Journal of Gastronomy and Food Science, 7 , 20-26. http://dx.doi.org/10.1016/j.ijgfs.2016.12.003 
Gomes, P. M. A., Figueirêdo, R. M. F., \& Queiroz, A. J. M. (2002). Caracterização e isotermas de adsorção de umidade da polpa de acerola em pó. Revista Brasileira de Produtos Agroindustriais, 4(2), 157-165. http://dx.doi.org/10.15871/15178595/rbpa.v4n2p157-165

Guimarães, F. I. T., Caliari, M., \& Soares Junior, M. S. (2014). Instrumental analysis of texture, color and acceptance of instante dessert formulated with broken-rice graisn. Food Science and Technology Research, 20(4), 1-8. http://dx.doi.org/10.3136/fstr.20.785

Kirca, A., Özkan, M., \& Cemeroğlu, B. (2007). Storage stability of strawberry jam color enhanced with black carrot juice concentrate. Journal of Food Processing and Preservation, 31(5), 531-545. http://dx.doi.org/10.1111/j.1745-4549.2007.00140.x

Mauro, A. K., Silva, V. L. M., \& Freitas, M. C. J. (2010). Caracterização física, química e sensorial de cookies confeccionados com Farinha de Talo de Couve (FTC) e Farinha de Talo de Espinafre (FTE) ricas em fibra alimentar. Food Science and Technology (Campinas), 30(3), 719-728. http://dx.doi.org/10.1590/S0101-20612010000300024

Rezende, A. C. B. (2013). Conservação de espinafre (Tetragonia expansa) pelo emprego de radiação gama: aspectos físicoquímicos, microbiológicos e sensoriais (Tese de doutorado). Faculdade de Ciências Farmacêuticas, Universidade de São Paulo, São Paulo.

Rocha, D. S., \& Reed, E. (2014). Pigmentos Naturais em Alimentos e sua Importância para Saúde. Estudos, 41, 76-85.

Santos, J. R., \& Boêno, J. A. (2016). Muffins isentos de glúten e lactose desenvolvidos com resíduo de polpa de graviola. Revista de Agricultura Neotropical, 3(3), 42-51. http://dx.doi.org/10.32404/rean.v3i3.1207

Sanz, T., Salvador, E. A., Baixauli, E. R., \& Fiszman, S. M. (2009). Evaluation of four types of resistant starch in muffins. II. Effects in texture, colour and consumer response. European Food Research and Technology, 229(2), 197-204. http://dx.doi.org/10.1007/s00217-009-1040-1

Silva, A. C., Nonino, G. C. W., Calgaro, R. M., \& Balbi, M. E. (2018). Chemical and nutritional analysis of amaranto flour in muffins of banana for celíacos. Visão Acadêmica, 19, 21-26.

Sowmya, M., Jeyarani, T., Jyotsna, R., \& Indrani, D. (2009). Effect of replacement of fat with sesame oil and additives on rheological, microstructural, quality characteristics and fatty acid profile of cakes. Food Hydrocolloids, 23(7), 1827-1836. http://dx.doi.org/10.1016/j.foodhyd.2009.02.008

Storck, C. R., Nunes, G. L., Oliveira, B. B., \& Basso, C. (2013). Folhas, talos, cascas e sementes de vegetais: composição nutricional, aproveitamento na alimentação e análise sensorial de preparações. Ciência Rural, 43(3), 537-543. http://dx.doi.org/10.1590/S0103-84782013000300027 